\title{
Secretory pathways in Salmonella Typhimurium- induced fluid accumulation in the porcine small intestine
}

\author{
MARIE LOUISE GRØNDAHL, GERDA M. JENSEN, C. G. NIELSEN*, E. SKADHAUGE, \\ J. E. OLSEN $\dagger$ and M. B. HANSEN
}

Departments of Physiology and Anatomy, * Clinical Studies and Veterinary Microbiology, Royal Veterinary and Agricultural University, Bülowsvej 13, DK-1870 Frederiksberg C, Denmark

\begin{abstract}
The involvement of 5-hydroxytryptamine (5-HT) and $5-\mathrm{HT}_{3}$ receptors and prostaglandin $E_{2}\left(P_{G_{2}}\right)$ in Salmonella Typhimurium-induced fluid accumulation in the porcine small intestine was investigated. Salmonella Typhimurium $\left(10^{8}\right.$ and $\left.10^{10} \mathrm{cfu}\right)$ and cholera toxin (CT; $20 \mu \mathrm{g}$ ) were instilled for 8 and $11 \mathrm{~h}$ in ligated loops in the porcine jejunum and ileum. Fluid accumulation and concentrations of $\mathrm{Na}^{+}, \mathrm{K}^{+}, \mathrm{Cl}^{-}, 5-\mathrm{HT}$ and $\mathrm{PGE}_{2}$ in the fluid accumulated in the loops were measured. The fluid accumulation was also measured when Salmonella Typhimurium $\left(10^{10} \mathrm{cfu}\right)$ and CT $(20 \mu \mathrm{g})$ were instilled for $8 \mathrm{~h}$ in ligated loops in jejunum and ileum in pigs given subcutaneous injections of saline or the $5-\mathrm{HT}_{3}$ receptor antagonist ondansetron $(200 \mu \mathrm{g} / \mathrm{kg})$. Salmonella Typhimurium $\left(10^{10} \mathrm{cfu}\right)$ and $\mathrm{CT}$ both induced fluid accumulation in jejunum and ileum after 8 and $11 \mathrm{~h}$. Both treatments also induced an increase in luminal release of 5-HT and PGE . The accumulated fluid was iso-osmotic and hyperosmotic in CT- and Salmonella Typhimurium-treated loops, respectively. Ondansetron reduced the Typhimuriuminduced fluid accumulation in both jejunum and ileum by $c$. $40 \%$, while it failed to reduce the response to CT. These results demonstrate that 5-HT and PGE 2 are released and $5-\mathrm{HT}_{3}$ receptors activated in the secretory pathway of Typhimurium in the porcine small intestine.
\end{abstract}

\section{Introduction}

Salmonella enterica subspecies enterica serotype Typhimurium (hereafter denoted ST)-induced enteritis is an increasing problem in man in many developed countries [1], and a major problem affecting growing pigs in several parts of the world [2]. The mechanisms by which ST causes diarrhoea are poorly understood and have largely been extrapolated from work done in rodents. Bacterial invasion is not correlated with diarrhoea [3, 4], but an inflammatory response with influx of polymorphonuclear leucocytes is needed, as ST fails to induce fluid secretion in the absence of leucocyte influx [5]. Another virulence factor seems to be an enterotoxin with partial resemblance to cholera toxin (CT) and Escherichia coli heat-labile enterotoxin (LT) $[6,7]$, but despite the efforts of many groups of investigators a role for an enterotoxin in ST-induced secretion has not been defined. Unlike CT and LT, the

Received 23 April 1997; revised version accepted 18 June 1997.

Corresponding author: Dr M. L. Grøndahl.
ST enterotoxin is not secreted but must be extracted [8]. Enterotoxigenicity is not the sole criterion of virulence, but there is a correlation between expression of 'cholera-toxin-related antigen' (CTRA) and secretory response in the rabbit ileum [9]. It is assumed that after entering the epithelial cells the bacteria liberate CTRA, thus initiating secretion, and later inflammatory mediators will contribute to the secretory response $[1$, 10].

CT induces intestinal electrolyte and fluid secretion partly by direct stimulation of the enterocytes via GM1 activating adenylate cyclase, raising cAMP levels, and partly via a secretory reflex arc involving 5-hydroxytryptamine (5-HT) [11-13]. 5-HT is liberated from the enterochromaffin cells [14] and initiates a cascade of reactions involving both the release of eicosanoids, such as prostaglandin $\mathrm{E}_{2}\left(\mathrm{PGE}_{2}\right)$ [13], and activation of the enteric nervous system (ENS) $[11,15]$. The reflex arc is assumed to have cholinergic and serotonergic interneurons [16], while the efferent neuron releases vasoactive intestinal polypeptide [11, 17]. 
Like CT, ST and cell-free lysates of ST induce fluid secretion and an increase in mucosal cAMP [18] and prostaglandins [19]. The induced fluid secretion and the increase in cAMP and prostaglandins can be reduced by treatment with indomethacin (inhibitor of prostaglandin synthesis), ascribing a role for prostaglandins in the secretory processes at least in rodents $[3,19,20]$.

The aim of this study was to investigate a possible role of 5-HT and $\mathrm{PGE}_{2}$ in ST-induced secretion in the porcine small intestine, which, in addition to its own relevance for veterinary science, is regarded as an appropriate model for man for studying pathophysiological mechanisms of diarrhoea [21]. CT was used as a comparative positive control.

\section{Materials and methods}

\section{Animals}

Danish Landrace/Yorkshire cross-bred 9-10-week-old pigs $(18-20 \mathrm{~kg})$ were used. The animals did not show any clinical signs of diarrhoea or detectable salmonella infection, according to serum antibodies and faecal cultures. The pigs were fasted for $12 \mathrm{~h}$ before experiments, but had free access to sterile drinking water containing D-glucose $(55 \mathrm{~g} / \mathrm{L})$. All experiments followed ethical guidelines approved by the Danish animal experiment inspection.

\section{Bacterial strain and preparation of inoculum}

Strain $S$. Typhimurium 3389-1 (DT12) [22] was kindly provided by D. L. Baggesen, Danish National Veterinary Laboratory. The strain was isolated from a clinical case of salmonellosis in pigs. For use as inoculum, the strain was first checked for purity by plating on Blood Agar (Oxoid Blood Agar Base III with sterile calf blood $\mathrm{v} / \mathrm{v} 5 \%$ ). A single colony was inoculated into $5 \mathrm{ml}$ of LB broth (Bacto Tryptone, Difco, $10 \mathrm{~g} / \mathrm{L}$, Bacto Yeast Extract, Difco, $5 \mathrm{~g} / \mathrm{L}, \mathrm{NaCl}$ $5 \mathrm{~g} / \mathrm{L} ; \mathrm{pH} 7.5$ ) and incubated overnight at $37^{\circ} \mathrm{C}$. To obtain cells in logarithmic growth phase, $1 \mathrm{ml}$ of this culture was inoculated into $100 \mathrm{ml}$ of prewarmed LB and incubated with shaking at $37^{\circ} \mathrm{C}$ until the $\mathrm{OD}_{405}$ was 0.3 . Cells were concentrated by centrifugation at $4000 \mathrm{rpm}$ for $10 \mathrm{~min}$ at $30^{\circ} \mathrm{C}$ in a Heraeus Megafuge $1.0 \mathrm{R}$ with model 3360 rotor. Cells were resuspended in $2 \mathrm{ml}$ of 'Argenzio 4' solution (see experimental procedure) without glucose at the desired density. Viable counts $(\mathrm{cfu} / \mathrm{ml})$ of inoculum were determined by a standard plate count technique.

\section{Operative procedure}

General anaesthesia was induced by intravenous injection of propofol (Diprivan; Zeneca) $5-7 \mathrm{mg} / \mathrm{kg}$ and maintained throughout the experiment by inhalation of isoflurane (Forene; Abbott) in a semiclosed circle system. At the incision line, a long-acting local analgesic (bupivacaine, Marcain $0.5 \% ; 10 \mathrm{ml}$ ) was infiltrated into the skin and underlying tissues to avoid reactions from the nociceptive system. The nociceptive system of the pig is not influenced by isoflurane alone [23], so without local analgesic the sympathetic tone may increase under surgery and possibly alter secretory and absorptive processes in the gut.

Throughout the experiment the condition of the animal was monitored and the rectal temperature was kept at c. $38^{\circ} \mathrm{C}$ with a heated mattress. Blood pressure was monitored continuously via a catheter placed in the artery saphena, from which blood for blood-gas analysis was sampled every hour and the $\mathrm{PCO}_{2}$ was monitored and kept at c. $40 \mathrm{~mm} \mathrm{Hg}$ by controlled ventilation (average: rate $12 / \mathrm{min}$, tidal volume $10 \mathrm{ml} / \mathrm{kg}$ and fresh $\mathrm{O}_{2}$ gas flow $200 \mathrm{ml} / \mathrm{min}$ ). Supporting treatments included a continuous intravenous infusion of Ringer-acetate liq. $(160 \mathrm{ml} / \mathrm{h}$; $\mathrm{mmol} / \mathrm{L}: \mathrm{Na}^{+}$130, $\mathrm{K}^{+} 4, \mathrm{Ca}^{2+} 2, \mathrm{Mg}^{2+} 1, \mathrm{Cl}^{-} 112$ and $\mathrm{Ac}^{-} 30$ ).

A midline abdominal incision was made and loops in jejunum and ileum were prepared by ligating between the mesenteric vascular arcades, providing full blood supply during the experiment. The jejunal loops were located $0.3-6.0 \mathrm{~m}$ distal to the ligament of Treitz and the ileal loops were placed $6.0-0.1 \mathrm{~m}$ proximal to the ileocaecal valve. Loops were $20 \mathrm{~cm}$ in length and separated by a distance of $5 \mathrm{~cm}$.

\section{Experimental procedure}

Before preparing the loops, and again $6 \mathrm{~h}$ later, $10 \mathrm{ml}$ of saline alone was administered by subcutaneous (s.c.) injection. Each loop was inoculated in random order with $10 \mathrm{ml}$ of 'Argenzio-4' test solution [24] (mmol/L: $\mathrm{Na}^{+} 115, \mathrm{~K}^{+} 10, \mathrm{Cl}^{-} 80, \mathrm{HCO}_{3}{ }^{-} 45, \mathrm{D}-$ glucose $80 ; \mathrm{pH}$ 7.4) containing either log phase ST $10^{8} \mathrm{cfu} /$ loop $\left(\mathrm{ST} 10^{8}\right), 10^{10} \mathrm{cfu}$ loop $\left(\mathrm{ST} 10^{10}\right), 20 \mu \mathrm{g}$ of CT, or test solution alone ( $\mathrm{T}$, control), or loops were left unfilled (U). After filling, the loops were returned to the peritoneal cavity, and the abdomen was closed. Blood was sampled after $4 \mathrm{~h}$ and plasma was frozen until osmolality measurement. Just before removal of the loops, 2-ml samples were collected from the accumulated fluid by syringe. Empty loops were washed with $5 \mathrm{ml}$ of test solution before sampling. The samples were centrifuged at $900 \mathrm{~g}$ for $20 \mathrm{~min}$ and the supernates were frozen at $-20^{\circ} \mathrm{C}$ until analysis for $\mathrm{PGE}_{2}, 5-\mathrm{HT}$, osmolality and electrolytes. After 8 and $11 \mathrm{~h}$, half the numbers of loops from jejunum and ileum, respectively, were removed. The data from 8 -h instillation were used as controls for the ondansetron treatment.

\section{Experiments with ondansetron treatment}

The animals were given $10 \mathrm{ml}$ of saline containing the $5-\mathrm{HT}_{3}$ receptor antagonist ondansetron $(200 \mu \mathrm{g} / \mathrm{kg})$ 
(MW $=366$, Glaxo Wellcome, Middlesex $)$ by s.c. injection before surgery and again after $6 \mathrm{~h}$. Loops were prepared and in random order inoculated with $10 \mathrm{ml}$ of Argenzio-4 test solution containing ST10 10 , $20 \mu \mathrm{g}$ of CT, test solution (T) alone or left unfilled (U). The ondansetron dose of $200 \mu \mathrm{g} / \mathrm{kg}$ was chosen to ensure maximal antagonism, as $100 \mu \mathrm{g} / \mathrm{kg}$ maximally reduced CT-induced fluid accumulation in a short-term (4-h) experiment [25]. The loops were returned to the peritoneal cavity and removed after $8 \mathrm{~h}$.

After removal of the loops, the pig was killed by intracardial injection of pentobarbital sodium. Loops were weighed immediately with and without the fluid contents and then dried to constant weight. Fluid accumulation was calculated by simple subtraction. The fluid was centrifuged at $9000 \mathrm{~g}$ for $20 \mathrm{~min}$ and the supernates were frozen at $-20^{\circ} \mathrm{C}$ until osmolality and electrolyte determination. Finally the wet weight: dry weight ratio was calculated to uncover possible differences in intramural fluid accumulation. Fluid accumulation is expressed as $\mathrm{g} / \mathrm{g}$ dry loop per $8 \mathrm{~h}$ and $\mathrm{SEM} ; \mathrm{n}$ is the number of observations and $\mathrm{N}$ is the number of animals.

\section{Analytical procedures}

Osmolality (Advanced Wide-Range Osmometer 3W2; Advanced Instruments Inc., Needham Heights, MA, USA) and concentrations of $\mathrm{Na}^{+}, \mathrm{K}^{+}$(FLM3 Flamephotometer; Radiometer, Copenhagen, Denmark) and $\mathrm{Cl}^{-}$(CMT 10 Chloride titrator; Radiometer) were determined in the accumulated fluid and blood osmolality was determined. $\mathrm{PGE}_{2}$ analysis was performed by radioimmunoassay [26]. 5-HT levels were analysed by enzyme immunoassay (Immunotec, Marseilles, France) and high-performance liquid chromatography (HPLC) in the fluid from ST and CT loops, respectively. Because of the risk of contamination, 5HT concentrations in ST-containing fluid could not be measured by HPLC.

\section{Statistical analysis}

Results are expressed as the means and SEM. The time, segment and dose response data were analysed by three-way ANOVA and the data dealing with the effect of ondansetron were analysed by one-way ANOVA. Pairwise comparison was performed by Student's $t$-test with Bonferroni correction when there were more than two comparisons. Probability values $(p) \leqslant 0.05$ were considered significant.

\section{Results}

In all experiments, the fluid instilled into $\mathrm{T}$ loops was absorbed (Fig. 1) and U loops were empty (data not shown). In this, as in previous studies $[25,27,28]$, no indication of any effect in adjacent loops was found.

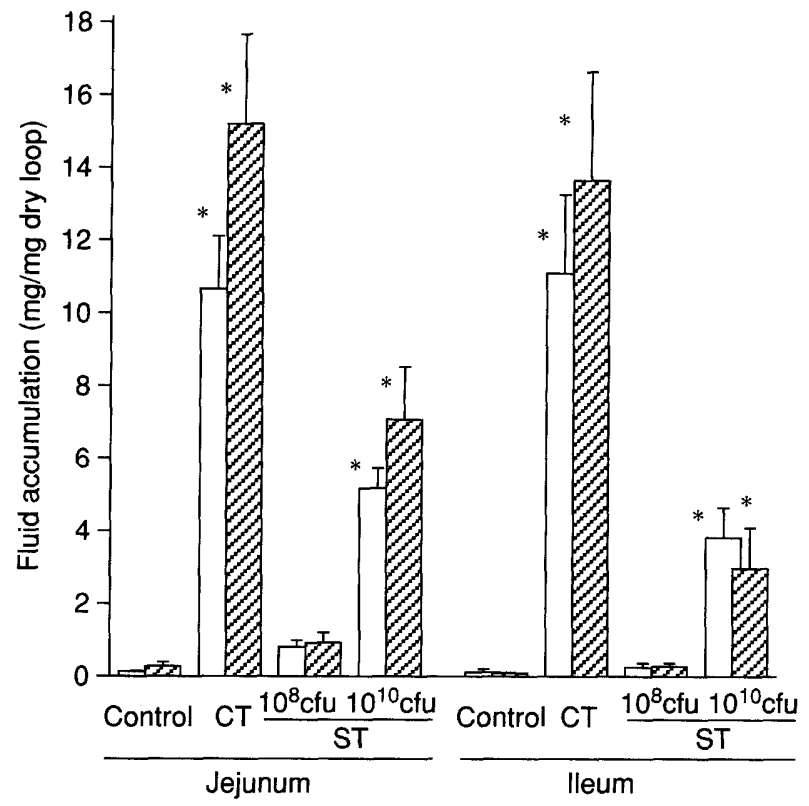

Fig. 1. Salmonella Typhimurium- $\left(10^{8}\right.$ and $\left.10^{10} \mathrm{cfu}\right)$ and cholera toxin- $(20 \mu \mathrm{g} / \mathrm{loop})$ induced fluid accumulation in ligated loops in porcine jejunum and ileum after $8(\square)$ and 11 ( $\square$ ( $) \mathrm{h}$ of instillation. Values are mean and SEM. Number of observations are $8-12$ in five animals. * Significant compared to control.

\section{ST-induced fluid accumulation (dose- and time- response, segmental differences)}

The three-way ANOVA showed no interaction between dose, time or segment and there was no statistically significant time-response. The test revealed differences in response to dose and segment. ST $10^{8} \mathrm{cfu}$ failed to induce a significant response (Fig. 1), whereas $10^{10} \mathrm{cfu}$ of ST induced fluid accumulation in jejenum and ileum after instillation for both 8 and $11 \mathrm{~h}$ (Fig. 1). The effect of $10^{10} \mathrm{cfu}$ was significantly higher than the effect of $10^{8} \mathrm{cfu}$. Segmental differences were only present in the fluid accumulation after $11 \mathrm{~h}$, showing a higher response in jejunum than in the ileum.

Wet weight: dry weight ratio of ST $10^{10}$ cfu-treated loops was significantly higher than the wet weight: dry weight ratio of $\mathrm{T}$ loops (data not shown).

\section{CT-induced fluid accumulation (time-response and segmental differences)}

$\mathrm{CT}$ induced fluid accumulation in jejunum and ileum after both 8 and $11 \mathrm{~h}$ (Fig. 1). Neither significant timeresponse nor segmental differences were present in the CT-induced fluid accumulation.

No difference was detected in the wet weight: dry weight ratio between CT-treated and $\mathrm{T}$ loops (data not shown). 


\section{5-HT and $P G E_{2}$ levels in accumulated fluid}

The data from 8 and $11 \mathrm{~h}$ was mixed, as no time response was evident (data not shown). The 5-HT and $\mathrm{PGE}_{2}$ levels in accumulated fluid from $\mathrm{T}$ (control), CTand ST-treated loops are shown in Table 1, Table 2 and Table 3. CT- and ST-treated loops had significantly higher levels of 5-HT and $\mathrm{PGE}_{2}$ in both segments than controls. No segmental differences were present in the 5-HT levels in either CT- or ST-treated loops. The $\mathrm{PGE}_{2}$ levels in CT-treated loops were also without segmental difference, whereas the levels of $\mathrm{PGE}_{2}$ were higher in jejunal than in ileal loops after ST stimulation.

\section{Osmolality and electrolyte concentrations}

Osmolality and $\mathrm{Na}^{+}, \mathrm{K}^{+}$and $\mathrm{Cl}^{-}$concentrations in accumulated fluid in CT- and ST-treated loops are

Table 1. Effect of CT on intraluminal 5-HT

\begin{tabular}{lcc}
\hline & Mean (SEM) 5-HT concentration (nmol/g dry loop) \\
\cline { 2 - 3 } Loop & \multicolumn{1}{c}{ Control } & CT \\
\hline Jejunum & 0.33 SEM 0.16 (3) & 3.9 SEM $0.74(5)^{*}$ \\
lleum & 0.44 SEM $0.17(4)$ & 2.7 SEM $0.78(5)^{*}$ \\
\hline
\end{tabular}

The 5-HT in the luminal accumulated fluid was measured by HPLC. Numbers in parentheses indicate the number of observations in three to five animals.

* Significant compared to control.

Table 2. Effect of ST on intraluminal 5-HT

\begin{tabular}{|c|c|c|}
\hline \multirow[b]{2}{*}{ Loop } & \multicolumn{2}{|c|}{ Mean (SEM) 5-HT concentration (nmol/g dry loop) } \\
\hline & Control & ST \\
\hline Jejunur & 0.88 SEM $0.23(7)$ & $3.47 \mathrm{SEM} 0.96(8)^{*}$ \\
\hline Ileum & 0.95 SEM 0.45 & 4.51 SEM $1.12(10)^{*}$ \\
\hline
\end{tabular}

The 5-HT in the luminal accumulated fluid was measured by enzyme immunossay. Numbers in parentheses indicate the number of observations in three to five animals.

* Significant compared to control. shown in Table 4. Segmental difference was present only in the $\mathrm{Cl}^{-}$concentration and the anion gap in CTinduced fluid accumulation, showing a higher jejunal than ileal $\mathrm{Cl}^{-}$concentration and a higher ileal than jejunal $\mathrm{HCO}_{3}{ }^{-}$concentration, as the anion gap is assumed mainly to represent $\mathrm{HCO}_{3}{ }^{-}$. The osmolality values in CT-treated loops did not differ from plasma osmolality, which was $262 \mathrm{SEM} 4 \mathrm{mOsm} / \mathrm{kg} \mathrm{H}_{2} \mathrm{O}$ $(\mathrm{n}=5, \mathrm{~N}=5)$, whereas the ST-induced accumulated fluid was hyperosmotic. No segmental differences in electrolyte composition were present in ST-induced accumulated fluid, whereas all electrolyte concentrations differed from values in CT-treated loops: there were lower $\mathrm{Na}^{+}$levels and higher $\mathrm{K}^{+}$levels in both segments, whereas $\mathrm{Cl}^{-}$concentration was lower in the jejunum and higher in the ileum when compared with CT-treated loops. The anion gap was also without any segmental difference and in the ileum it was significantly lower than in CT-treated jejunal loops.

\section{Effect of ondansetron}

As shown in Fig. 2, ondansetron treatment reduced the ST-induced fluid accumulation by $c .40 \%$ in both jejunum and ileum, while ondansetron failed to have an effect on the response to CT. Ondansetron did not affect fluid accumulation in $\mathrm{T}$ and $\mathrm{U}$ loops (data not shown). The systolic blood pressure was increased from 73.4 SEM $8.7 \mathrm{~mm} \mathrm{Hg}(\mathrm{n}=22, \mathrm{~N}=6)$ to $85.3 \mathrm{SEM}$ $2.5 \mathrm{~mm} \mathrm{Hg}(\mathrm{n}=24, \mathrm{~N}=6)$ by the ondansetron treatment.

\section{Discussion}

The main purpose of this study was to test the hypothesis that 5-HT plays a role in ST-induced secretion. The study demonstrated that $5-\mathrm{HT}$ is released to the luminal fluid in the small intestine and that the $5-\mathrm{HT}_{3}$ receptor antagonist ondansetron reduces the fluid

Table 3. Effect of CT and ST on intraluminal $\mathrm{PGE}_{2}$

\begin{tabular}{|c|c|c|c|}
\hline \multirow[b]{2}{*}{ Loop } & \multicolumn{3}{|c|}{ Mean (SEM) $\mathrm{PGE}_{2}$ concentration (ng/g dry loop) } \\
\hline & Control & ST & $\mathrm{CT}$ \\
\hline Jejunum & 4.5 SEM $0.7(14)$ & 22.3 SEM $4.5(19)^{*}$ & 22.8 SEM $8.6(15)^{*}$ \\
\hline Ileum & 3.3 SEM $0.3(16)$ & 9.7 SEM $2.4(18)^{*}$ & 21.1 SEM $8.1(15)^{*}$ \\
\hline
\end{tabular}

Numbers in parentheses indicate the number of observations in three animals.

* Significant compared to control.

Table 4. Osmolality and $\mathrm{Na}^{+}, \mathrm{K}^{+}$and $\mathrm{Cl}^{-}$concentrations in accumulated fluid after stimulation by CT and ST

\begin{tabular}{lccccc}
\hline Agent, loop & $\begin{array}{c}\text { Osmolality } \\
\left(\mathrm{m} \mathrm{Osm} / \mathrm{kg} \mathrm{H}_{2} \mathrm{O}\right)\end{array}$ & $\mathrm{Na}^{+}(\mathrm{nmol} / \mathrm{L})$ & $\mathrm{K}^{+}(\mathrm{nmol} / \mathrm{L})$ & $\mathrm{Cl}^{-}(\mathrm{nmol} / \mathrm{L})$ & Anion gap \\
\hline CT, jejunum & 282 SEM 6 & 140 SEM 2 & 8.8 SEM 0.5 & 105 SEM 13 & 44 SEM 13 \\
CT, ileum & 278 SEM 9 & 140 SEM 3 & 8.7 SEM 0.8 & 50 SEM 3 & 99 SEM 5 \\
ST, jejunum & 342 SEM 18 & 127 SEM 2 & 15.5 SEM 0.9 & 80 SEM 5 & 62 SEM 5 \\
ST, ileum & 334 SEM 18 & 131 SEM 3 & 14.1 SEM 1.1 & 87 SEM 5 & 58 SEM 6 \\
\hline
\end{tabular}

$\mathrm{mmol} / 1$ and osmolality in $\mathrm{mOsm} / \mathrm{kg} \mathrm{H} \mathrm{H}_{2} \mathrm{O}$. There were $8-12$ observations in four animals. The anion gap was calculated by subtracting the $\mathrm{Cl}^{-}$concentration from the sum of $\mathrm{Na}^{+}$and $\mathrm{K}^{+}$concentrations. 


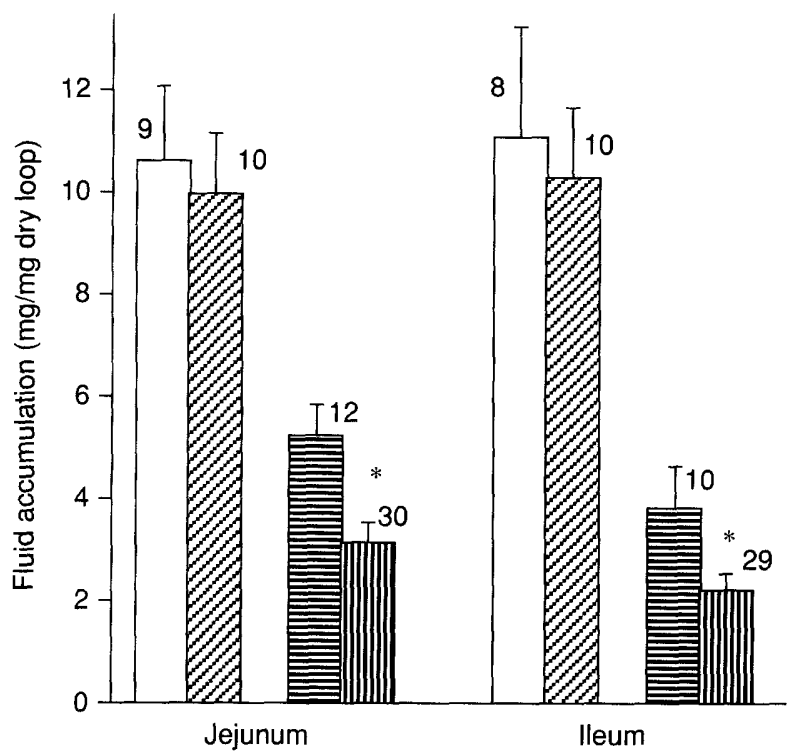

Fig. 2. Effect of ondansetron on Salmonella Typhimurium- $\left(10^{8} \mathrm{cfu}\right)$ and cholera toxin- $(20 \mu \mathrm{g} / \mathrm{loop})$ induced fluid accumulation in ligated loops in porcine jejunum and ileum after $8 \mathrm{~h}$ of instillation: $\square, \mathrm{CT}$; $\mathbb{Q}$, $\mathrm{CT}+$ ondansetron; III!, ST; $\mathrm{ST}$ + ondansetron. Values are mean and SEM. The figures indicate number of observations in five to seven animals. *Significant compared to control.

accumulation induced by ST. These findings support the hypothesis.

The secretory responses to CT and ST are often compared, as they both induce massive electrolyte and fluid secretion, and some strains of ST produce an enterotoxin that resembles CT [6]. CT is the best studied secretagogue, which makes it ideal as a reference, but the gastrointestinal tract, in some regards, exhibits different responses to CT and ST. Unlike CT stimulation, histopathological changes are observed in ST infection [29,30]. After $8 \mathrm{~h}$ of ST instillation in ligated loops in pigs [2] and rabbits [4], mucosal alterations have been reported with massive infiltration of polymorphnuclear leucocytes (PMNL) in the lamina propria, many of which transmigrate the epithelial lining. Crypts are dilated by PMNL debris ('crypt abscess') and lined by attenuated epithelium [2]. The intensity of the reaction is greatest over Peyer's patches [2], in accordance with M-cells having been suggested to be an entrance for the ST infection [31]. Villus atrophy due to extrusion of the villus tip is not present until $12 \mathrm{~h}$ after instillation [4]. Besides these histological differences, CT and ST have different cytokine profiles in the induced accumulated fluid [29].

The potency of CT and ST could not be compared with accuracy, as the doses of CT and ST are not directly comparable. For this, further dose- and timeresponse studies are needed.

As previously reported in rats [13], pigs [32] and man $[33,34], \mathrm{CT}$ induced fluid accumulation and a rise in intraluminal 5-HT and $\mathrm{PGE}_{2}$. Both 5-HT and $\mathrm{PGE}_{2}$ induce secretion by direct stimulation of the enterocytes [35] and by activating the ENS [36]. Furthermore, $\mathrm{PGE}_{2}$ suppresses ileal $\mathrm{Na}^{+}$and water absorption $[37,38]$. No intramural fluid accumulation was observed after CT stimulation, consistent with CT inducing secretion without histological changes [30].

The 5-HT receptors participating in fluid and electrolyte secretion include at least $\mathrm{G}$ protein-linked $5-\mathrm{HT}_{2 \mathrm{~A}}$, $5-\mathrm{HT}_{4}$ receptors and the $5-\mathrm{HT}_{3}$ ligand-gated ion channels $[16,39-41]$, with some species differences $[16,39,42-47]$. The $5-\mathrm{HT}_{2}$ receptors are situated on neurons and enterocytes, the $5-\mathrm{HT}_{3}$ receptors are largely located on neuronal structures $[16,48]$ and $5-\mathrm{HT}_{4}$ receptors are located on neurons and intestinal smooth muscles [49].

In this study, treatment with ondansetron - a potent and highly selective 5- $\mathrm{HT}_{3}$ receptor antagonist [50] failed to reduce the CT-induced fluid accumulation, which is in contrast to previous findings [25] that showed a $40 \%$ reduction in response to $\mathrm{CT}$ by ondansetron. The differences may be due to different experimental design, as Grøndahl and co-workers [25] used an instillation time of only $4 \mathrm{~h}$, younger pigs (68 weeks, $12-15 \mathrm{~kg}$ ) and halothane as general anaesthetic. Time dependency in the secretory mechanism of CT has been suggested by Wald and co-workers [51]. Thus 5-HT may be involved mainly in the early phase of the secretion, which could explain the failure of reduction by ondansetron in the present study. The use of different anaesthetics may also influence the effect of ondansetron, as several anaesthetics modulate the 5- $\mathrm{HT}_{3}$ receptor-mediated functions [52]. Finally, the CT dose $(20 \mu \mathrm{g})$ that induced a submaximal fluid accumulation in the 4-h experiment [25], left the loops completely filled (ballooning) after $8 \mathrm{~h}$. This increased intraluminal pressure may have influenced the secretory response of CT and thereby also the antagonistic effect of ondansetron.

The ondansetron treatment induced an increase in the systolic blood pressure, which is consistent with inhibition of the Bezold-Jarisch reflex, which can be stimulated by 5 -HT injections $[53,54]$.

Analysis of the loop contents demonstrated that CT induced secretion of iso-osmotic fluid and electrolyte composition as previously reported $[25,55]$. The lower $\mathrm{Cl}^{-}$concentration in ileum may reveal a decreased $\mathrm{Cl}^{-}$secretion in accordance with decreasing amount of $\mathrm{Cl}^{-}$channels, CFTR, in the aboral direction of the small intestine [56], or an increased $\mathrm{Cl}^{-} / \mathrm{HCO}_{3}{ }^{-}$ exchange in ileum, or both [53]; thus $\mathrm{HCO}_{3}{ }^{-}$probably explains the anion gap.

ST induced a dose-dependent fluid accumulation as reported in rabbits [58]. The $\mathrm{PGE}_{2}$ level in the accumulated fluid was increased, consistent with ST inducing increase of mucosal prostaglandin concentra- 
tion after installation in rabbit ileal loops [19]. $\mathrm{PGE}_{2}$ is involved in the response both via inflammation and the enterotoxin, as both ST enterotoxin [20] and nontoxigenic ST [59] induce secretion involving prostaglandins. The source of the $\mathrm{PGE}_{2}$ is believed to be the fibroblasts, as cell culture of porcine fibroblasts have been shown to produce PGE in response to inflammatory mediators such as 5-HT, bradykinin, histamine, adenosine and platelet activating factor [35]. Furthermore, Duebbert and Peterson [19] suggest that epithelial prostaglandin production occurs after ST stimulation. The higher amount of $\mathrm{PGE}_{2}$ and fluid accumulated in the jejunum than in the ileum reveal segmental differences in the secretory response to stimulation with ST, which confirm the importance of studying ST infections in more than one segment [10]. Also, the luminal content of 5-HT was increased after stimulation with ST. The EC cells are supposed to be the major source of the 5-HT release as described for $\mathrm{CT}$ [14]. The secretory pathways for $\mathrm{PGE}_{2}$ and 5-HT are discussed above. In addition, other inflammatory mediators may have contributed to the fluid accumulation, as several have been shown to have both direct and indirect secretory effects on the intestinal epithelium, via ENS [35, 60, 61]. Consistent with an inflammatory reaction in the intestinal wall, intramural fluid accumulation was observed in the ST-treated loops.

The hyperosmolality of the accumulated fluid observed in the ST loops is probably due to products of bacteriolysis, contributing to an osmotic component in the stimulated fluid accumulation. A consistently lower $\mathrm{Na}^{+}$concentration was present in ST-treated loops than with $\mathrm{CT}$. Likewise, the high $\mathrm{K}^{+}$concentration could be explained by $\mathrm{K}^{+}$release from bacteriolysis and damaged epithelial cells [2]. No segmental difference was present in the $\mathrm{Cl}^{-}$concentration and anion gap, which may indicate stimulated $\mathrm{HCO}_{3}{ }^{-}$ secretion in both segments.

Ondansetron reduced the ST-induced fluid accumulation by $c$. $40 \%$. This inhibitory effect of ondansetron is probably due partly to inhibition of the secretory effect of the released 5-HT and partly to an inhibition of the secretory nervous reflexes activated by inflammation mediators [59].

It is not possible from these data to determine whether the involvement of 5-HT in the secretory response is mainly through the secretory pathway of an enterotoxin or through inflammatory mediators. Further loop-test studies with cell-free lysates of enterotoxigenic ST and with enterotoxin-negative ST strains are needed.

In summary, these data demonstrate that Salmonella Typhimurium - like CT - causes release of 5-HT and $\mathrm{PGE}_{2}$ into the lumen and fluid accumulation in the porcine small intestine. Furthermore, ondansetron reduces the fluid accumulation induced by ST by about one-third in both jejunum and ileum. Taken together, these results suggest that $5-\mathrm{HT}$ is released and $5-\mathrm{HT}_{3}$ receptors activated in the secretory pathway of ST. Furthermore, the involvement of prostaglandins in ST induced secretion is confirmed in the porcine small intestine.

This work was supported by the Danish Agricultural and Veterinary Research Council (grant No. 13-4538-1), the Velux (1981) Foundation, Novo Nordisk Foundation and the Vetfond, Denmark. We thank B. Nielsen for serological and microbiological analysis, P. Christensen for RIA analysis and Annica Dahlström for HPLC analysis; Birgitte Holle, Iben Thomsen, Gitte Christensen, and Anja Borum for excellent assistance with experiments, and D. Jensen and Tina Otto for their skilled handling of animals.

\section{References}

1. Stephen J, Amin II, Douce GR. Experimental Salmonella typhimurium-induced gastroenteritis. In: Cabello FC (ed) Biology of Salmonella. New York, Plenum Press. 1993: 199209.

2. Reed WM, Olander HJ, Thacker HL. Studies on the pathogenesis of Salmonella typhimurium and Salmonella choleraesuis var kunzendorf infection in weanling pigs. Am J Vet Res 1986; 47: 75-83.

3. Giannella MD, Gots RE, Charney AN, Greenough WB, Formal SB. Pathogenesis of Salmonella-mediated intestinal fluid secretion. Activation of adenylate cyclase and inhibition by indomethacin Gastroenterology 1975; 69: 1238-1245.

4. Wallis TS, Starkey WG, Stephen J, Haddon SJ, Osborne MP, Candy DC. Enterotoxin production by Salmonella typhimurium strains of different virulence. $J$ Med Microbiol 1986; 21: 19 23.

5. Wallis TS, Hawker RJH, Candy DCA et al. Quantification of the leucocyte influx into rabbit ileal loops induced by strains of Salmonella typhimurium of different virulence. $J$ Med Microbiol 1989; 30: 149-156.

6. Finkelstein RA, Marchlewicz BA, McDonald RJ, BoesmanFinkelstein $M$. Isolation and characterization of a cholerarelated enterotoxin from Salmonella typhimurium. FEMS Microbiol Lett 1983; 17: 239-241.

7. Chopra AK, Peterson JW, Houston CW, Pericas R, Prasad R. Enterotoxin-associated DNA sequence homology between Salmonella species and Escherichia coli. FEMS Microbiol Lett 1991; 77: 133-138.

8. Wallis TS, Starkey WG, Stephen J, Haddon SJ, Osborne MP, Candy DCA. The nature and role of mucosal damage in relation to Salmonella typhimurium-induced fluid secretion in the rabbit ileum. J Med Microbiol 1986; 22: 39-49.

9. Clarke GJ, Qi G-M, Wallis TS et al. Expression of an antigen in strains of Salmonella typhimurium which react with antibodies to cholera toxin. $J$ Med Microbiol 1988; 25: 139145 .

10. Stephen J, Wallis TS, Starkey WG, Candy DC, Osborne MP, Haddon S. Salmonellosis; in retrospect and prospect. Ciba Found Symp 1985; 112: 175-192.

11. Sjöqvist A, Cassuto J, Jodal $M$, Lundgren $O$. Actions of serotonin antagonists on cholera-toxin-induced intestinal fluid secretion. Acta Physiol Scand 1992; 145: 229-237.

12. Cassuto J, Jodal M, Tuttle R, Lundgren O. 5-hydroxytryptamine and cholera secretion. Physiological and pharmacological studies in cats and rats. Scand J Gastroenterol 1982; 17: 695703.

13. Beubler E, Kollar G, Saria A, Bukhave K, Rask-Madsen J. Involvement of 5-hydroxytryptamine, prostaglandin E2, and cyclic adenosine monophosphate in cholera toxin-induced fluid secretion in the small intestine of the rat in vivo. Gastroenterology 1989; 96: 368-376.

14. Nilsson $\mathrm{O}$, Cassuto J, Larsson PA et al. 5-Hydroxytryptamine and cholera secretion: a histochemical and physiological study in cats. Gut 1983; 24: 542-548.

15. Cassuto J, Siewert A, Jodal M, Lundgren O. The involvement of intramural nerves in cholera toxin-induced intestinal 
secretion. Acta Physiol Scand 1983; 117: 195-202.

16. Hansen MB. Serotonin - an intestinal secretagogue - receptor subtypes and intracellular mediators. Pharmacol Toxicol 1995; 77 Suppl 1: 3-39.

17. Cassuto J, Fahrenkrug J, Jodal M, Tuttle R, Lundgren $O$. Release of vasoactive intestinal polypeptide from the cat small intestine exposed to cholera toxin. Gut 1981; 22: 958-963.

18. Peterson JW, Molina NC, Houston CW, Fader RC. Elevated cAMP in intestinal epithelial cells during experimental cholera and salmonellosis. Toxicon 1983; 21: 761-775.

19. Duebbert IE, Peterson JW. Enterotoxin-induced fluid accumulation during experimental salmonellosis and cholera: involvement of prostaglandin synthesis by intestinal cells. Toxicon 1985; 23: $157-172$

20. Khurana S, Ganguly NK, Khullar M, Panigrahi D, Walia BNS. Studies on the mechanism of Salmonella typhimurium enterotoxin-induced diarrhoea. Biochim Biophys Acta 1991; 1097: $171-176$

21. Argenzio RA. The pig in studies of diarrhea pathophysiology. In: Tumbleson $M$ (ed) Swine in biomedical research. New York, Plenum Press. 1986: 10-22.

22. Nielsen B, Baggesen D, Bager F, Haugegaard J, Lind P. The serological response to Salmonella serovars typhimurium and infantis in experimentally infected pigs. The time course followed with an indirect anti-LPS ELISA and bacteriological examinations. Vet Microbiol 1995; 47: 205-218.

23. Benson GJ. Perioperative pain and stress. In: Thurman TC (ed) Lumbs and Jones' Veterinary anesthesia. Baltimore, Williams and Wilkins: 1996.

24. Argenzio RA. Glucose-stimulated fluid absorption in the small intestine during the early stage of swine dysentery. Am J Vet Res 1980; 41: 2000-2006.

25. Grøndahl ML, Jensen GM, Skadhauge E, Hansen MB. Effect of 5-HT2 and 5-HT3 receptor antagonists on cholera toxininduced fluid hypersecretion in the pig jejunum. Zentralbl Veterinarmed A 1996; 43: 543-552.

26. Christensen P, Leyssac PP. A specific radioimmunoassay for PGE2 using antibody with high specificity and sephadex LH20 microcolumn for the separation of prostaglandins. Prostaglandins 1976; 11: 399-420.

27. McEwan GT, Schousboe B, Nielsen CG, Skadhauge E. Effect of age on the secretory capacity of pig small intestine in vivo and in vitro. Am J Physiol 1990; 259: G474-G480.

28. Grøndahl ML, Hansen MB, Larsen IE, Skadhauge E. Age and segmental differences in 5-HT-induced hypersection in the pig small intestine. J Comp Physiol [B] 1996; 166: 21-29.

29. Klimpel GR, Asuncion M, Haithcoat J, Niesel DW. Cholera toxin and Salmonella typhimurium induce different cytokine profiles in the gastrointestinal tract. Infect Immun 1995; 63: $1134-1137$.

30. Hansen MB, Tindholdt TT, Elbrønd VS et al. The effect of alpha-trinositol on cholera toxin-induced hypersecretion and morphological changes in pig jejunum. Pharmacol Toxicol 1996; 78: 104-110.

31. Neutra MR, Frey A, Kraehenbuhl J-P. Epithelial M Cells: gateways for mucosal infection and immunization. Cell 1996; 86: $345-348$.

32. Peterson JW, Whipp SC. Comparison of the mechanisms of action of cholera toxin and the heat-stable enterotoxins of Escherichia coli. Infect Immun 1995; 63: 1452-1461.

33. Bearcroft D, Perrett D, Farthing MJG. 5-Hydroxytryptamine release into human jejunum by cholera toxin. Gut 1996; 39: 528-531.

34. Speelman P, Rabbani GH, Bukhave K, Rask-Madsen J. Increased jejunal fluid prostaglandin E2 in patients with acute cholera. Gut 1985; 26: $188-193$.

35. Berschneider HM. Fibroblast modulation of intestinal secretory responses. In: Stead RH (ed) Neuro-immuno-physiology of the gastrointestinal mucosa. New York, The New York Academy of Sciences. 1992: 140-147.

36. Brunsson I, Sjöqvist A, Jodal M, Lundgren O. Mechanisms underlying the small intestinal fluid secretion caused by arachidonic acid, prostaglandin E1 and prostaglandin E2 in the rat in vivo. Acta Physiol Scand 1987; 130: 633-642.

37. Al-Awqati Q, Greenough WB. Prostaglandins inhibit intestinal sodium transport. Nature 1972; 238: 26-28.

38. Vigneulle RM, Kitto G, McVittie TJ, Dubois A. Intraluminal infusion of a prostaglandin E2 analog suppresses intestinal absorption. Gastroenterology 1990; 98: A559 (Abstract).

39. Beubler E, Coupar IM, Hardcastle J, Hardcastle PT. Stimulatory effects of 5-hydroxytryptamine on fluid secretion and transmural potential difference in rat small intestine are mediated by different receptor subtypes. $J$ Pharm Pharmacol 1990; 42: 35-39.

40. Bunce KT, Elswood CJ, Ball MT. Investigation of the 5hydroxytryptamine receptor mechanism mediating the shortcircuit current response in rat colon. Br J Pharmacol 1991; 102: $811-816$.

41. Hindle AT. Recent developments in the physiology and pharmacology of 5-hydroxytryptamine. Br J Anaesth 1994; 73: $395-407$

42. Hoyer D, Clarke DE, Fozard JR et al. International Union of Pharmacology classification of receptors for 5-hydroxytryptamine (Serotonin). Pharmacol Rev 1994; 46: 157-203.

43. Nelson DL, Lucaites VL, Audia JE, Nissen JS, Wainscott DB. Species differences in the pharmacology of the 5-hydroxytryptamine 2 receptor: structurally specific differentiation by ergolines and tryptamines. J Pharmacol Exp Ther 1993; 265: $1272-1279$.

44. Watson A, Abbott A. TIPS Receptor Nomenclature Supplement. January 1992. Trends Pharmacol Sci 1991; 12: suppl 1suppl 13.

45. Zimmerman TW, Binder HJ. Serotonin-induced alteration of colonic electrolyte transport in the rat. Gastroenterology 1984; 86: $310-317$.

46. Kilpatrick GJ, Bunce KT, Tyers MB. 5-HT3 receptors Med Res Rev 1990; 10: 441-475.

47. Munck LK, Eskerod O, Hansen MB, Bukhave K, Rask-Madsen J. Failure of tropisetron to inhibit jejunal water and electrolyte secretion induced by 5-hydroxytryptamine in healthy volunteers. Gut 1994; 35: 637-640.

48. Siriwardena AK, Smith EH, Borum EH, Kellum JM Identification of a 5-hydroxytryptamine (5-HT2) receptor on guinea pig small intestinal crypt cells. Am J Physiol 1993; 265: G339-G346.

49. Bockaert J, Fozard JR, Dumuis A, Clarke DE. The 5-HT4 receptor: a place in the sun. Trends Pharmacol Sci 1992; 13: $141-145$.

50. Peroutka SJ. 5-Hydroxytryptamine receptors. $J$ Neurochem 1993; 60: 408-416.

51. Wald A, Gotterer GS, Rajendra GR, Turjman NA, Hendrix TR. Effect of indomethacin on cholera-induced fluid movement, unidirectional sodium fluxes, and intestinal cAMP. Gastroenterology 1977; 72: 106-110

52. Parker RMC, Bentley KR, Barnes NM. Allosteric modulation of 5-HT3 receptors: focus on alcohols and anaesthetic agents. Trends Pharmacol Sci 1996 17: 95-99.

53. Saxena PR, Villalon CM. Cardiovascular effects of serotonin agonists and antagonists. J Cardiovasc Pharmacol 1990; 15 suppl 7: S17-S34.

54. McQueen DS, Mir Ak. 5-Hydroxytryptamine and cardiopulmonary and carotid body reflex mechanisms. In: Fozard JR (ed) The peripheral actions of 5-hydroxytryptamine. Oxford, Oxford University Press. 1989: 301-321.

55. Lange S, Lönnroth I, Skadhauge E. Effects of the antisecretory factors in pigs. Pflügers Arch 1987; 409: 328-332.

56. Trezise AEO, Buchwald $M$. In vivo cell-specific expression of the cystic fibrosis transmembrane conductance regulator Nature 1991; 353: 434-437.

57. Chang EB, Rao MC. Intestinal water and electrolyte transport. In: Johnson LR (ed) Physiology of the gastrointestinal tract. New York, Raven Press. 1994: 2027-2082.

58. Giannella RA, Formal SB, Dammin GJ, Collins H. Pathogenesis of salmonellosis. Studies of fluid secretion, mucosal invasion, and morphologic reaction with the rabbit ileum. $J$ Clin Invest 1973; 52: 441-453.

59. Brunsson I. Enteric nerves mediate the fluid secretory response due to Salmonella typhimurium R5 infection in the rat small intestine. Acta Physiol Scand 1987; 131: 609-617.

60. Nash S, Parkos C, Nusrat A, Delp C, Madara JL. In vitro model of intestinal crypt abscess. A novel neutrophil-derived secretagogue activity. J Clin Invest 1991; 87: 1474-1477.

61. Powell DW. New paradigms for the pathophysiology of infectious diarrhea. Gastroenterology 1994; 106: 1705-1707. 